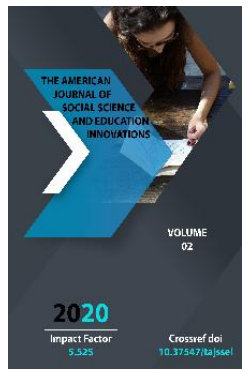

Journal Website: http://usajournalshub.c om/index,php/tajssei

Copyright: Original content from this work may be used under the terms of the creative commons attributes 4.0 licence.

\section{From The History Of Ethnic And Ethnogenetic Relations On The Natural-Economic Borders Established Under The Anthropogenic Landscape Of The Iron Age Of The Khorezm}

Yusupov Ahmadjon Shonazarovich

Lecturer, History Faculty, Urgench State University, Urgench, Uzbekistan

Abdullayeva Mohira Saparboy Qizi

Student, Department Of History, History Faculty, Urgench State University, Urgench, Uzbekistan

\title{
ABSTRACT
}

This article analyzes ethnic and ethnogenetic relations in the natural and economic boundaries of the Khorezm oasis under the influence of the anthropogenic landscape of the Iron Age.

\section{KEYWORDS}

Amudarya, Syrdarya, anthropogenic landscape, lower Amudarya, cultural and economic centers.

\section{INTRODUCTION}

According to the results of geological research and the achievements of geography in the Khorezm oasis and the adjacent Sariqamishboyi border, the formation of the anthropogenic landscape of the Iron Age, its development by the population According to the data recorded in geographical scientific publications, 25-10 million years ago the area between the Yellow Sea and the Aral Sea basin was flat.[1] According to the results of geological surveys conducted by the Khorezm archeological and ethnographic expedition in the Khorezm plain, in the Tertiary and Quaternary periods of land geology, due to the Amudarya, the vast plain from Uzboy to the Aral Sea did According to archeological 
research.[2] The Amudarya, its tributaries, the Syrdarya and its Janadarya and Inkar rivers played an important role in the formation of the Aral Sea basin.[3]

The paleogeographic condition of the borders of the Lower Amudarya Sariqamish and the Uzbek coast is reflected in a special monograph.[4] The vast area from Shorakhan to Sultan Uvays Mountain is the southern Akchadarya, the area between the Kyzylkum sand dunes and the Aral Sea is the northern Akchadarya.[5]

\section{MATERIALS AND METHODS}

The paleography of the right bank of the Amudarya is described by the Kyzylkum Barkhans, the basins, the Beltov Plateau and the Sultan Uvays Mountain, of which Karatag is a part. The left bank is radically different from the right bank in terms of paleogeography. The sand dunes of the Karakum Desert, the basins, the Kozaliqir, Qalaliqir, Yassiqir, Tuzqir, Butentov, Kangqaqir, Mangir, and the Sariqamish Lake and Tuni rivers formed by the inflow of water reflect the paleogeography of the left bank boundaries.[6] In the historiography of the twentieth century, there is no information about the history of human occupation of the foothills of Sultan Uvays.

According to historical data, ancient stone, Mesolithic, Neolithic stone tools were found in the south-eastern part of Ustyurt.[7] Thus, the paleogeographic situation of the southeastern part of Ustyurt allowed mankind to determine its location and occupation. Based on the logical conclusion of the theoretical and comparative analysis of historical data recorded in scientific publications, the Ustyurt region has a mild glacial nature and a unique historical process. According to the results of archeological excavations carried out by E.A. Vinogradova in the foothills of Sultan Uvays, in the last Stone Age, mankind turned this land into an ethnic space. In fact, it is only natural that people come to this region from different directions, or that there are ideas about indigenous peoples. In our opinion, the hunters in Ustyurt migrated to the foothills of the Sultan Uvays Mountain due to the ecological situation.[8] At the end of the 4th millennium $B C$-first quarter of the 4th millennium $B C$, the heirs of the Late Stone Age people at the foot of Sultan Uvays Mountain are connected to the foothills of the northern, northwestern and northeastern watersheds of Yonboshkala, located in the southeast. who founded the first ethnic space, living on the side of the height. The data presented in the publications of the XAЭ staff describe the anthropogenic landscape and paleogeography of the lowlands connected to the foothills of the Akchadarya Basin as a result of its activities. Thus, in the last stage of the Neolithic period, new generations of tribal communities, under the guidance of the "Wise Mother", demonstrated the paleography of the Kyzylkum. Thus, around the Yonboshkala plateau, it was assimilated by tribal communities in the late Neolithic period, leading to qualitative changes in its paleogeography and becoming the first ethnic sites.[9] Neolithic tribal communities continued the ethnic unity of the oasis. According to the historical data recorded in the scientific literature, the new generations of Neolithic tribes in the Khorezm oasis, given the high population density, aimed to develop new natural and economic areas in the middle of the second half of the IV millennium BC. For this purpose, the Uzboy, Sariqamishboy and Tuyamoyin districts were developed and ethnic areas were created. In fact, along with the lower basins of the Amudarya, the Sariqamish basin, the predominant spreading 
water basins around Uzboy, the area adjacent to its shores, tugai and reed fields, and water basins formed as a result of rising and falling water levels.[10] The formation of the earth's poleogeography at a certain time under the influence of the sun created favorable conditions for the arrival and settlement of the first Neolithic tribal communities and the continuation of the ancestral occupation.

\section{RESULT AND DISCUSSION}

In an article by M.A. Itina on archeological excavations around Tuyamoyin, there were no changes in the cartography of ethnic processes during the Bronze Age.[11] However, due to water shortages in Uzboy and Sariqamishboy, they moved to the Akchadarya basin, to the land of their ancestors. This ethnic migration lasted from the end of the 2nd millennium $B C$ to the 7 th century BC. Thus, by the end of the Bronze Age, ethnic relations included the central, southern and Tuyamoyin areas of the Akchadarya basin. By the beginning of the first millennium $B C$, radical changes had taken place in the history of ethnicity and ethnogenesis. During this historical period, the Southern Akchadarya, the area around the Quyisoy plateau south of the Sariqamish basin, formed the poliogeography of the first Iron Age ethnic processes. It should be noted that the increase in population in the Southern Akchadarya region since the 7 th century $B C$, the occasional sharp drop in water levels, the development of livestock on a larger scale. caused his comrades to leave and move for the purpose of exploitation. Towards the end of the Iron Age, a policy was pursued in the Khorezm oasis and the surrounding Sariqamish area at the initiative of the tribal chief. . This process continued on and around Lake Sariqamish, which was formed on the shores of the Amudarya by the Davdon and Darya rivers.

\section{CONCLUSION}

Thus, the above comments have led to the following final conclusion.

- The first stage of the ethnic process in Khorezm covered the area of Sultan Uvays, and this process lasted until the last period.

- At the end of the second half of the IV millennium BC - III millennium BC, the areas around Akchadarya, Sariqamishboy, Uzboy and the left bank Tuyamoyin became ethnic sites.

- In the II millennium BC, ethnic sites continued to function in the Akchadarya Tuyamoyin region.

- On this historical date, the activities of ethnic sites in Sariqamishboy and Uzboy regions came to an end.

- From the end of the second millennium BC, the activities of the ethnic areas around Tuyamoyin and Sariqamish were completed. The ethnic process continued in the Akchadarya basin.

\section{REFERENCES}

1. Baratov P., Mamatkulov M., Rafikov.A. Natural geography of Central Asia. Tashkent: Teacher. 2005. p.-283.

2. KesA.C. Anthropogenic impact on the formation of the alluvial-deltaic plains of the Amu Darya // Culture and art of ancient Khorezm.-M.: Nauka, 1981.-P. 73.

3. Weinberg B.I. Ecology of the Aral Sea region in antiquity and the Middle Ages // Ethnographic Review. Moscow: Nauka, No. 1, 1997.-p. 24. .

4. Lower reaches of the Amu Darya, Sarygamysh, Uzbay. History of formation 
and settlement // MHE, Issue. 3.- Moscow: Nauka, 1960. -p. 3-348.

5. Lower reaches of the Amu Darya, Sarygamysh, Uzbay. History of formation and settlement // MHE, Issue. 3.- Moscow: Nauka, 1960. -p. 35-39.

6. Kes.AS Riverbed Uzbay and its genesis / M, "Science" 1939. Issue-30 y̆sha muallif. Natural trading posts that determined the settlement of ancient people in the deserts of Central Asia / KSIE, Vyp-XXX M, 1958; Baratov P., Mamatkulov M., Rafikov A. Natural geography of Central Asia. Tashkent: Teacher. 2005. p.-170-172.

7. Vinogradova EA, Bizhanov EB First paleolithic finds from South-Eastern Ustyurt / AO 1977. M .: Nauka, 1978.

8. Vinogradova E.A. The first paleolithic finds of Sultanuizdag // Priaralye in antiquity and the Middle Ages. Moscow, IVL, RAN, Nauka, 1998. P.74-77.

9. Tolstov S.P. Ancient Khorezm. M.: Nauka, 1948. - p. 59-66. Gulomov Ya.G. History of irrigation in Khorezm. T .: 1959. p.-44-46.

10. Itina M.A. History of the steppe tribes of the Southern Aral Sea region // Tr KhAE M .: Nauka, 1977. T-X; Itina M.A. Monuments of the Neolithic and Bronze Age. // KhAE M .: Nauka, 1977. T-X, -p. 66-79; Matyakubov $\mathrm{H}$. Khorezm oasis of the Bronze Age and the first Iron Age. - Tashkent: National Library of Uzbekistan Publishing House. 2017. p.-14-15.

11. Itina M.A. Monuments of the Neolithic and Bronze Age) KhAE, Moscow: Nauka, 1977 T-X, p.66-79. 